\title{
ESTIMATION OF THE THERAPEUTICAL VALUE OF DRIED POLYPHENOLIC EXTRACTS FROM TWO PLANTS OF DOBROGEA SPONTANEOUS FLORA
}

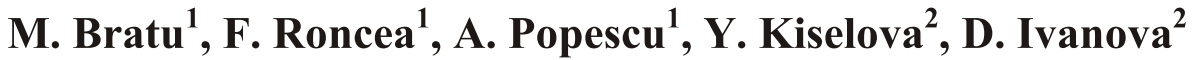 \\ 1 “Ovidius" University, Faculty of Dental Medicine and Pharmacy, Pharmacy Department, \\ Constanta, Romania, ${ }^{2}$ Varna Medical University, Faculty of Medicine, Department of Preclinical, \\ Clinical Pharmacology, Chemistry and Biochemistry, Varna, Bulgaria \\ Reviewed by: Assoc. Prof. T. Yankova, MD, PhD
}

\begin{abstract}
Our study involves Sophora japonica L. and Holoschoenus vulgaris L. both plants from Dobrogea' spontaneous flora. In order to establish the therapeutic value we measured the total polyphenol content (Folin Ciocslteu method) and the total antioxidant activity (by ABTS radical decolorization assay) of the dried extracts obtained under different working conditions. All the dried extracts' features presented are according to the general monograph Extracta quality conditions, $<0,04 \%$ iron and heavy metals content, and dried substance $<5 \%$. The higher total antioxidant capacity and total polyphenol content were observed in Sophora extract no.1, correlated with a certain raw material/solvent ratio (1/5), time of extraction (8 hours). These preliminary data obtained for TEAC and TP content lead us to conclude that the extracts could have an important therapeutical value possibly confirmed by future studies involving animal testing.
\end{abstract}

Keywords: antioxidant capacity, polyphenol content

\section{INTRODUCTION}

Holoschoenus vulgaris L. (Cyperaceae), synonym Scirpus holoschoenus L. (Figure 1) is a rare herbaceous perennial plant, one meter high, with a round-headed club-rush, flowering in April - July.

European distribution: France, Greece, Italy, Portugal, Spain. Widespread in the entire Mediterranean basin, extending along the coasts of the Black Sea, in particular in dunal systems, north to the Dobrogea and the Danube Delta, in valleys of the Balkan peninsula north to the Banat (15).

From the phytochemical point of view, Holoschoenus vulgaris L. has not been previously investigated.

From a medicinal point of view, the crude extract of. Scirpus americanus (11) and Scirpus maritimus (12) exhibited significant activity against lymphocytic leukemia, rhizomes extract from Scirpus lacustris showed bacterial activity against Escherichia coli (8) and stilbene trimmers isolated from the tubers of $S$. fluviatilis behave as antiallergic and anti-inflammatory agents (1). Traditionally, people from Dobrogea region use the boiled extract from the rhizomes of Holoschoenus vulgaris L. for its hepatic-protective activity.

M. Bratu, "Ovidius" University, Faculty of Dental Medicine and Pharmacy, Pharmacy Department, Constanta, Romania

E-mail: bratu-farma@univ-ovidius.ro

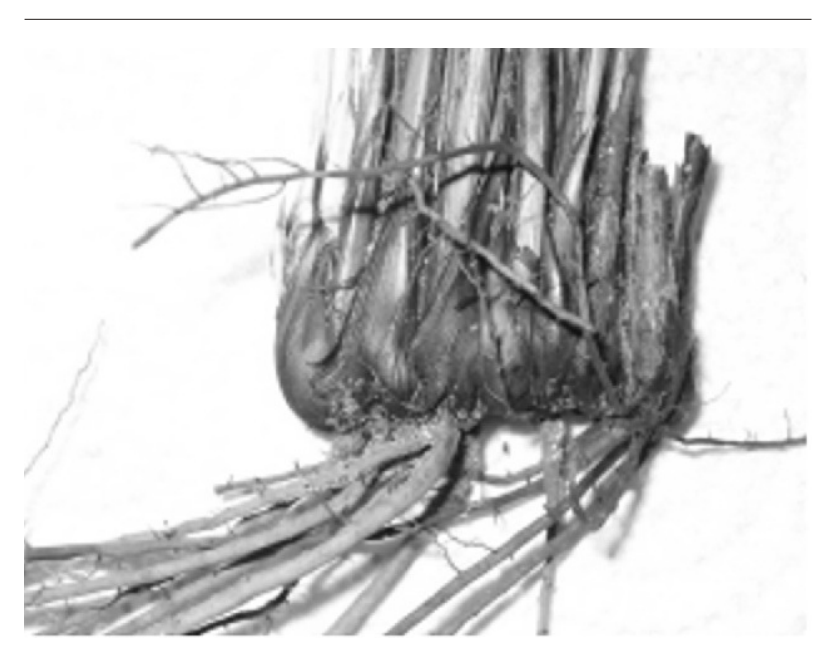

Figure 1. Holoschoeni rhizoma

Sophora buds come from the Sophora japonica L. (Fabaceae) tree (Figure 2), (also known as the Japanese pagoda), a deciduous tree native to east Asia and cultivated in China, Japan and Korea and in Bulgaria and Romania. The flowers of the sophora tree are hermaphrodite and flower in late August and early September. The flower buds represent raw material for rutin (flavonoid) extraction over $15-20 \%$, and quercetin (obtained by hydrolysis) and pectines (2). 
Flavonoids (mainly rutin and quercetin) are able to modulate the activity of some enzymes and to modify the behaviour of many cell systems suggesting that they could exert a multitude of biological activities, particularly significant antioxidant, vasculoprotective, antihepatotoxic, antiallergic, anti-inflammatory, antiulcerogenic and even antitumoral activities and are capable to exhibit metal ion chelating effect. $(3,4,7)$.

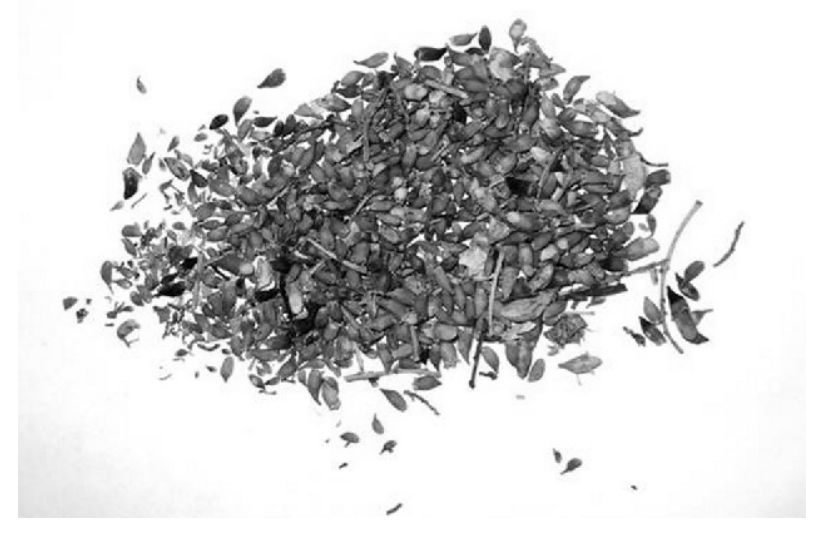

Figure 2. Sophorae flower buds

\section{MATERIAL AND METHODS}

\section{Plant material}

Sophora japonica flower buds were collected from Constanta area in July - August 2005, they were dried in a dark place, at room temperature. Botanical identification was done according to the morphologic features (macro and microscopic examinations).

Table 1. Extraction procedure for Sophora flower buds and Holoschoeni rhizoma

\begin{tabular}{||c|c|c|c||}
\hline \hline Extract No. & $\begin{array}{c}\text { Raw material/ } \\
40 \% \text { methanol }\end{array}$ & $\begin{array}{c}\text { Time } \\
\text { (hours) }\end{array}$ & $\begin{array}{c}\text { Hydrolisys } \\
\text { (HCl 10\%, 1:1), } \\
\text { (hours) }\end{array}$ \\
\hline 1. Sophora flower buds & $1: 5$ & - & 8 \\
\hline 2. Sophora flower buds & $1: 10$ & - & 16 \\
\hline 3. Sophora flower buds & $1: 15$ & - & 24 \\
\hline 4. Holoschoeni rhizoma & $1: 7.5$ & 6 & - \\
\hline \hline
\end{tabular}

The plant rhizomes from Holoschoenus vulgaris (Cyperaceae) were collected from Tulcea County during September - October 2005, dried on air, grounded and extracted with different solvents, in order to separate the components. Botanical identification was done according to the morphologic features (macro and microscopic examinations). Dried extracts were obtained under different working conditions from flower buds of Sophora japonica (Table 1) and roots of Holoschoenus vulgaris (Table 1) and were analysed according to Extracta monograph (European
Pharmacopoeia and Romanian Pharmacopoeia $X^{\text {th }}$ edition) $(3,4,7)$.

The chemical composition of all extracts was established by a general chemical analysis of aetheric, alcoholic and water extracts $(5,6)$.

\section{Determination of the total polyphenol content}

Total polyphenol content was measured using the Folin-Ciocalteu reagent as described by Singleton and Rossi (1965) (14) with slight modifications. Samples (150 $\mu \mathrm{L})$ were introduced into test tubes; $750 \mu \mathrm{L}$ of Folin-Ciocalteu's reagent and $600 \mu \mathrm{L}$ of sodium carbonate (7.5\%) were added. The tubes were mixed and incubated at $50^{\circ} \mathrm{C}$ for $10 \mathrm{~min}$. Absorption at $760 \mathrm{~nm}$ was measured on spectrophotometer Spekol 11 (Carl Zeiss Jena, Germany). Quercetin was used as a standard. The total phenolic content was expressed as $\mathrm{mM}$ Quercetin Equivalents $(\mathrm{QE})$. Results are presentedm as means \pm S.D. Each measurement was performed at least in triplicate. Quercetin, sodium carbonate and Folin-Ciocalteu's reagent were obtained from Sigma-Aldrich Chemie GmbH, Taufkirchen, Germany. Measurement of antioxidant activity of the working solution $0.5 \mathrm{~g}$ of Sophora japonica and Holoschoenus vulgaris extracts were diluted in $100 \mathrm{ml} 40 \%$ ethanol and stirred continuously at RT to the full dilution of the extract. After 10 min of centrifugation (x $4000 \mathrm{~g}$ ) the supernatant was used for biochemical measurements. The total antioxidant capacity of aqueous-alcoholic plant extracts was determined by the ABTS (2, 2'-azinobis (3-ethylbenzothiazoline -6-sulfonic acid)) radical decolorization assay (13). The method is based on the consumption of preformed in the presence of potassium persulfate $\mathrm{ABTS}$ radical $\left(\mathrm{ABTS}^{\circ}{ }^{\circ}\right.$ ) whose absorption maximum is at $734 \mathrm{~nm}$. Addition of antioxidants to $\mathrm{ABTS}^{\text {+ै }}$ reduces it to $\mathrm{ABTS} .10 \mu \mathrm{L}$ plant extract was added to $1000 \mu \mathrm{L}$ ABTS + in $5 \mu \mathrm{M}$ phosphate buffered saline, $\mathrm{pH} 7.4$, (PBS), with absorption adjusted to $0.700 \pm 0.02$. The decrease of the absorption was measured after six minutes.

Alpha-tocopherol in methanol and Trolox (registered trade-mark of Hoffman-LaRoche, 6-hydroxy-2,5,7,8tetramethychroman-2-carboxylic acid) were used as a standard. The antioxidant activity is presented as $\mathrm{mM}$ Trolox equivalent antioxidant capacity, (TEAC). The results are presented as means \pm S.D. Each measurement was performed at least in triplicate. Analysis was carried out on spectrophotometer Spekol 11 (Carl Zeiss Jena, Germany).

\section{RESULTS AND DISCUSSION}

Botanical identification of the plant material was carried out by macro and macroscopic examinations of the flower buds from Sophora japonica L. (Fabaceae) and of rhizome from Holoschoenus vulgaris L. (Cyperaceae).

The 3 dried extracts obtained in different working conditions from Sophora japonica flower buds L. (Table 1) presented as brown crystals, soluble in methanol and ethanol had an iron and heavy metal content $<0,04 \%$ and dried substance 3,89\% (extract 1), 3,94\% (extract 2), 4,56\% (extract 
3). The dry extract from Holoschoenus vulgaris roots presented as brown crystals, soluble in methanol, ethanol, contained mainly polyphenols (Arnow test), and had an iron and heavy metal content $<0,04 \%$ and dried substance $2,30 \%$. These data were in accordance to the general monograph Extracta quality conditions for dried extracts (less than $<0,04 \%$ iron and heavy metals content, and $<5 \%$ dried substance).
Chemical analysis of the dried extracts showed the presence of flavonoids (rutin), polyphenols (Arnow test), mucilages and pectines for Sophora flower buds extracts and the presence of sterols, triterpenes, coumarines, reducing compounds, oses and polioses, tannins, contain mainly polyphenols (Arnow test) for Holoschoenus vulgaris roots extract (Table 2).

Aqueous ethanolic extracts corresponding to the 3 dried ex-

Table 2. Chemical analysis of dried extracts from Sophora flower buds and Holoschoeni rhizoma

\begin{tabular}{|c|c|c|c|c|}
\hline Nr. & Solution & Reaction & Intensity & $\begin{array}{l}\text { Active principles } \\
\text { identificated }\end{array}$ \\
\hline 1. Sophora flower buds extract & Aetheric & Shibata & $+1+$ & flavonols \\
\hline 2. Holoschoeni rhizome extract & Aetheric & $\begin{array}{c}\text { Shibata } \\
\text { Lieberman - Burchard } \\
\text { U.V. }(\lambda=365 \mathrm{~nm})\end{array}$ & $\begin{array}{l}+1 \\
+ \\
+\end{array}$ & $\begin{array}{l}\text { flavonols } \\
\text { sterols } \\
\text { coumarins }\end{array}$ \\
\hline 3. Sophora flower buds extract & Alcoholic & Fehling & + & reduced compounds \\
\hline 4. Holoschoeni rhizome extract & Alcoholic & Fehling & + & reduced compounds \\
\hline 5. Sophora flower buds extract & Alcoholic hydrolised & $\begin{array}{l}\text { Shibata } \\
\text { Arnow }\end{array}$ & $\begin{array}{l}+ \\
+\end{array}$ & $\begin{array}{c}\text { flavonols } \\
\text { polyphenols }\end{array}$ \\
\hline 6. Holoschoeni rhizome extract & Alcoholic hydrolised & $\begin{array}{c}\text { Lieberman - Burchard } \\
\text { Arnow }\end{array}$ & $\begin{array}{l}+ \\
+\end{array}$ & $\begin{array}{c}\text { sterols } \\
\text { polyphenols }\end{array}$ \\
\hline 7. Sophora flower buds extract & Aquaoeus & $\begin{array}{c}\text { Fehling } \\
\mathrm{H}_{2} \mathrm{SO}_{4} \text { conc. + timol }\end{array}$ & $\begin{array}{l}+ \\
+ \\
+\end{array}$ & $\begin{array}{l}\text { reduced compounds } \\
\text { oze, polioze- }\end{array}$ \\
\hline 8. Holoschoeni rhizome extract & Aquaoeus & $\begin{array}{c}\text { Fehling } \\
\mathrm{H}_{2} \mathrm{SO}_{4} \text { conc. + timol } \\
\mathrm{FeCl}_{3} \\
\text { Styasny }\end{array}$ & $\begin{array}{l}+ \\
+ \\
+ \\
+\end{array}$ & $\begin{array}{l}\text { reduced compounds } \\
\text { oze, polioze } \\
\text { taninuri } \\
\text { tanin catehic }\end{array}$ \\
\hline
\end{tabular}

Table 3. Total polyphenol and total antioxidant capacity of Sophora flower buds extracts and Holoschoeni rhizoma extract.

\begin{tabular}{||l|c|c||}
\hline \hline Extract No & $\begin{array}{c}\text { Total polyphenol } \\
\text { content (TP) } \\
\boldsymbol{\mu M} \pm \text { SD }\end{array}$ & $\begin{array}{c}\text { Total antioxidant } \\
\text { capacity (TEAC) } \\
\mathbf{m M} \pm \text { SD }\end{array}$ \\
\hline $\begin{array}{l}\text { 1. Sophora } \\
\text { flower buds }\end{array}$ & 3732.167 .23 & 16.940 .15 \\
\hline $\begin{array}{l}\text { 2. Sophora } \\
\text { flower buds }\end{array}$ & 3585.084 .55 & 15.530 .71 \\
\hline $\begin{array}{l}\text { 3. Sophora } \\
\text { flower buds }\end{array}$ & 3118.4223 .73 & 14.810 .23 \\
\hline $\begin{array}{l}\text { 4. Holoschoeni } \\
\text { rhizoma }\end{array}$ & 2060.0429 .75 & 8.210 .27 \\
\hline \hline
\end{tabular}

tracts from Sophora japonica flower buds and that from Holoschoenus vulgaris roots were studied for TEAC and TP content (Table 3 ) in order to select the extract with the greatest content in TP and a higher antioxidant potential, possibly explaining their therapeutical uses and select appropriate conditions for extraction.

Aqueous ethanolic extracts from Sophora japonica buds exhibited high TEAC values that could be measured only at 8 times dilution. The results indicated a good antioxidants content, especially in extract $1(16.94 \pm 0.15 \mathrm{mM})$, and were related to the results of the chemical analysis (rutin, polyphenols). Higher dilutions (20 times) produced similar results for the TEAC, especially for extracts 1 and 2 (data not shown). According to our previous results the method produces slightly higher values when measurements are performed at higher dilutions (9).

TP content was measured at 20 times dilution and extract 1 was found to be not only the one with the highest TEAC value but also with highest TP content $(3732.16 \pm 7.23 \mu \mathrm{M})$. 
This allows us to conclude that TEAC and TP values are also related to the extraction procedure, and the results suggest that a raw material/solvent ratio (1:5), $8 \mathrm{~h}$ hydrolysis with $\mathrm{HCl} 10 \%$, resulted in the highest TP content. High polyphenol content might be the explanation for the high TEAC values, according to a previously established correlation (10).

TEAC and TP values for aqueous ethanolic extracts from Holoschoenus vulgaris roots were determined at 8 times dilution (Table 3). These values also show a high polyphenol content, correlated with the results of chemical analysis, and a good value for the antioxidant potential.

\section{CONCLUSION}

Our preliminary data about TEAC and TP content lead us to conclude that the extracts could have an important therapeutical value, which will possibly be confirmed by future studies involving animal testing. We assume that these are preliminary results and that we will improve the extraction procedure (raw material / solvent ratio, vary in solvents, and hydrolysis time).

\section{REFERENCES}

1. Abdel-Mogib, M., S. A. Basaif, T. R. Sobahi. Stilbenes and a new cetophenone derivative from Scirpus holoschoenus.- Molecules, 6, 2001, No 8, 663-667.

2. Bruneton I. In: Pharmacognosie, Phytochimie, Plantes Medicinales, Technique et Documentation. Lavoisier, ed. Paris, 1993, 218, 249, 258.

3. Ciulei I., E. Grigorescu, U. Stanescu. In: Plante medicinale. Fitochimie si fitoterapie. Editura Medicalã, Bucuresti, 1, 1993, 346- 348.
4. Ciulei I., V. Istudor, M. Palade, D. Albulescu, E. C. GBrd. In: Analiza farmacognostica si fitochimica a produselor vegetale. Tehnoplast Company, Bucuresti, 2, 1995, 409-418

5. European Pharmacopoeia. (Ph.Eur. 3rd edition), Council of Europe, Strasbourg, Supplement 2001.

6. Farmacopeea Roman. (editia X). Editura Medicala, Bucuresti, 1993, 1035-1038, 1043-1046, 1053-1055, 1057-1058, 1063.

7. Istudor V. In: Farmacognozie, fitochimie, fitoterapie. Editura Medicalr, Bucureeti, 1, 1998, 145-156.

8. Kichuth, R., G. Kaitzis. Microbizid wirksame Aromaten aus Scirpus lacustris L. -Forum Umwelthygiene, 26, 1975, No 4-5, 134-135.

9. Kiselova Y., B. Galunska, D. Ivanova, T. Yankova. Total antioxidant capacity and polyphenol content correlation in aqueous-alcoholic plant extracts used in phytotherapy. -Scripta Scientifica Medica, 36, 2004, 11-13.

10. Kiselova Y, D. Ivanova, T. Chervenkov, D. Gerova, B. Galunska, T. Yankova. Correlation between the in vitro antioxidant activity and polyphenol content of aqueous extracts from Bulgarian herbs. -Phytother. Res., 20, 2006, in press.

11. Miles, D.H., A. A. De La Cruz. Estuarine Processes.-Proc. 3rd Int. Estuarine Res. Conf, 1, 1976, 267, (C.A. 87, 114549n).

12. Powell, R. G., R. Bajaj, J. L. McLaughlin. Bioactive stilbenes of Scirpus maritimus.-J. Nat. Prod., 50, 1987, No 2, 293-296.

13. Re, R., N. Pellegrini, A. Prottegente, A. Pannala, M. Yang, C. Rice-Evans. Antioxidant activity applying an improved ABTS radical cation decolorization assay. -Free Rad. Biol. Med., 26, 1999, 1231-37.

14. Singleton, V.L., J. A. Rossi. Colorimetry of total phenolics with phosphomolybdic-phosphotungstic acid reagent. -Am. J. Enol. Viticult. 16, 1965, 144-58.

15. www.natural resources 